\title{
New Synthesis of Early Medieval Iron Hoards from Slovakia
}

\author{
Mária Múllerová
}

\begin{abstract}
The aim of this article is to present a theory on early medieval hoards of iron implements from the region of Slovakia. The chronological range is from the end of the $8^{\text {th }}$ to the beginning of the $10^{\text {th }}$ century. 74 known hoards will be classified using a statistical factor analysis, principal component analysis. This type of analysis enables identification of the variability and the most common iron implements and their combinations that appear in early medieval hoards. Attention will also be focused on the occurrence of specific objects in a hoard, for example warriors' equipment, agricultural tools or axe-shaped bars, as well as the locations and contexts in which the depots were found. An examination of the excavation circumstances will also be included in order better to understand the results of the principal component analysis. This study will provide a more complete picture of hoards in Slovakia with particular emphasis on hoards of iron implements. It will enable the formation or creation and deposition of hoards in particular places to be interpreted and better understood. The use of statistical methods will further enable a deeper understanding of the theory of hoards in the early medieval period.
\end{abstract}

\section{Keywords}

Early medieval period, hoard, iron implements, axe-shaped bars, principal component analysis, Slovakia.

Zusammenfassung - Nene Synthese frübmittelalterlicher Eisenbortfunde aus der Slowakei

Ziel des Artikels ist es, eine Theorie zu frühmittelalterlichen Hortfunden bestehend aus Eisengegenständen aus der Slowakei vorzustellen. Der chronologische Rahmen reicht vom Ende des 8. bis zum Beginn des 10. Jhs., der geografische Bereich liegt vor allem im Hochgebirge und in unmittelbarer Nähe der Zentren Großmährens, im Nordwesten und vereinzelt in der Südslowakei. Die in dieser Studie enthaltenen 74 Hortfunde wurden mit der Hauptkomponentenanalyse (PCA) statistisch analysiert. Mithilfe dieser Methode können wir die häufige Korrelation zwischen gehorteten Artefakten erkennen. Die PCA isolierte zuerst drei Gruppen von Hauptkomponenten (drei Faktoren), die Hortfunde in der Slowakei charakterisieren. Die typischsten Artefakte in den untersuchten Horten sind landwirtschaftliche Werkzeuge (erster Faktor), dann folgt der zweite Faktor mit handwerklichen Werkzeugen und der dritte, der bipolare Faktor, mit Haushaltswerkzeugen, Kriegerausrüstung, Sicheln und Axenbarren. Diese Faktoren wurden auch in Bezug auf die Ausgrabungsumstände und die Fundkontexte (Siedlungen, Burgwälle oder unbekannte Verhältnisse) untersucht. Auf diese Weise war es möglich, jeden Faktor mit bestimmten Umständen zu verbinden. Die Analyse ermöglicht es, die Variabilität und Häufigkeit der Eisengegenstände sowie ihre Kombinationen, die in frühmittelalterlichen Horten auftreten, zu identifizieren. Die Verwendung der PCA in dieser Studie kann als neuer Ansatz zum Verständnis frühmittelalterlicher Horte in der Slowakei sowie des umfassenderen Phänomens der Hortfunde in der Archäologie angesehen werden. Dies könnte auch eine neue Möglichkeit sein, die potenzielle Beziehung zwischen dem Menschen und den verwendeten Werkzeugen zu verstehen.

\section{Schlüsselbegriffe}

Frühmittelalter, Hortfund, Eisengegenstände, Hauptkomponentenanalyse, Slowakei.

\section{Introduction}

The problem of hoards and hoarding has been dealt with by a number of scholars, both archaeologists and historians, and is also the topic of this article. The aim of this paper is to give a brief synthesis of our research into the patterns of hoards and the hoarding of iron in early medieval Slovakia. Early medieval hoards in Slovakia mainly contain iron implements: a wide range of tools, from agricultural tools through craft tools to axe-shaped bars, which form a special group of hoards of iron implements.

Principal component analysis (factor analysis) (in the following, PCA/FA) is used here, because the two main research questions for this article could be answered with the help of statistics. The first question is about the (possible) relationship between the tools in the hoard: is there some relationship between the tools? Which were most frequently put into the hoard together and which are never found in one hoard? The second question concerns the value: is it possible to define some value of iron based on the iron implements in hoards? Why did people in early medieval times deposit iron instead of precious metals such as gold or silver?

By using multivariate statistical methods, it is possible to discover the connection or correlation between tools in hoards. This relationship between a wide range of tools reveals another type of information: information about the 
most typically used tools in hoards, what kinds of tools are found together in one hoard and what kinds of tools are never found together. For synthesis, in general, means creating and connecting new archaeological structures. The structures express order, regularity or relation in the studied sources, ${ }^{1}$ in this case, early medieval hoards with iron implements. A great advantage in using PCA/FA is that it has the ability to organize not only descriptors (tools in hoards, the circumstances) but also objects like sites, where the hoards were found (see sections 5 and 6). ${ }^{2}$

This article focuses on the Slovakian hoards which were already published. The first analysis was carried out by publishing the specific hoards, where the dating, types of tools, typology or find circumstances are reported. I decided to look at them in another way: the focus is only on the kind of artefacts/tools which were found in the hoard. For example, does the hoard contain axe-shaped bars, axes, coulters etc.? Also important are the find circumstances, for it is possible that the location may be a means for understanding the whole process of hoarding in early medieval times. With the help of PCA it is possible to predict what kind of hoard was found in specific places and whether the hoards with agricultural tools were found in settlements or not.

\section{Understanding Hoards}

This article defines hoarding in a way that enables us to separate hoards from other archaeological features. The paper works with hoards containing at least two artefacts. The hoard itself can be viewed not just as an archaeological feature, but also as an artefact, more specifically a composite artefact. Composite artefacts are made up from other artefacts and are intentionally created or modified by humans. ${ }^{3}$ According to Evźen Neustupnýs definition of artefacts, a hoard can be understood as a witness or manifestation of past societies and extinct cultures. ${ }^{4}$

The distribution of hoards in many cases seems to mirror the intention behind their deposition. Typically we distinguish between votive and non-votive (ritual and non-ritual) hoards. According to Richard Bradley, votive hoards are frequently found in places of no return like swamps, by or in rivers, etc. ${ }^{5}$ Some of the Slovakian hoards with iron implements considered here seem to belong to this group, for

\footnotetext{
1 Neustupný 2007, 21.

2 NeustupnÝ 2007,135.

3 NeUSTUPNÝ 2007, 31-32.

4 Neustupný 2010, 38.

5 Bradley 1990, 11.
}

example one from the Moravský Ján (36) ${ }^{6}$ site, which was deposited next to the river Morava, and one from the Zádiel $(71)^{7}$ site, which was deposited by the forest stream. A further, no less interesting hoard from Bratislava I (18) was found within a circle of skeletons and might also be considered a votive hoard. ${ }^{8}$ It may also be classified as a hoard deposited near graves, which have been known from examples since ancient times, said to be due to the 'protection' the dead provide for the valuables. ${ }^{9}$ Non-votive (non-ritual) hoards were usually interpreted as the concealment of possessions from plundering foreign armies. For example, during civil disorder and dangerous times in Great Moravia, temporary hiding places were created. For a number of reasons, many of these fortunes were never recovered, until the present, when they were found during excavations, accidently or by treasure hunters. One of the main problems of hoard evidence is that it only shows us those hoards which were not recovered. Those which were recovered of course escape our knowledge. These kinds of hoards are also known by the term 'Angstdepot' - hidden out of fear. ${ }^{10}$

Before getting into details, we have to clarify the terminology: what is a hoard? At the beginning of the $20^{\text {th }}$ century, in 1903, Oscar Montelius established the first definition of a hoard as "... a definite find... [which] can be viewed as the sum or collection of items which were found in such circumstances that they can be considered to have been deposited together at one time. Most items from older time periods, which are important for this question, are usually found in old settlements or in graves. Others were placed as a 'depot', in the ground or in the water. Items that were accidentally lost are not really relevant here as they are mostly found on their own."11

The 'Encyclopedic Dictionary of Archaeology' states that a hoard is "[a]ny collection of objects, buried at one time. A deliberate deposit of complete or broken objects buried in the ground for subsequent recovery or as a symbolic act. A hoard often included valuables or prized possessions." 12 This definition essentially covers most research on hoards. Bohuslav Novotný, who edited the 'Encyclopedia of Archaeology' in 1986, revised Montelius' hoard definition as "[i]ntentionally hidden or saved artefacts, deposited

6 BARToŠKovÁ 1986, 33. - ZА́воJNíк 2009, 103. - All mentioned sites are marked in Figure 1 and are listed in the catalogue (Appendix 1). The numbers given in the text correspond to those on the map and in the catalogue.

7 BARTOŠKová 1986, 60.

8 Bialeková 1990, 110.

9 See Gorecki 1995.

10 KÜNZL 1996, 469.

11 Montelius 1903, 10.

12 Kipfer 2000. 
for a particular reason, not just due to their value (amount, material or type)". ${ }^{13}$ How to understand the term depot is the particular subject of many studies and scientific analyses, which are not the subject of the present paper, and that is why the first basic definition and the definition which corresponds to the geographical area under investigation were chosen.

Can we indeed consider a couple of finds as a hoard without taking into account any other circumstances? Among others, the database contains a hoard from Modra (35). This hoard is not clearly considered a hoard. Despite having been included in the sample used here, it can be interpreted as two finds which were found together, but not necessarily deposited together. ${ }^{14}$ In the archaeological terminology of middle Europe a distinction is made between the terms depot - Hortfund (hoard) and bromadný nález - Mebrfund (multiple find: two or more finds found together at one place). Manfred K. Eggert divided the hoards into three categories, namely closed depots (Geschlossene Horte), unclosed depots (Nichtgeschlossene Horte) and isolated findings, as likely depots (Einzelfunde mit Hortcharakter).${ }^{15}$ The question whether to consider regarding one or two objects as a depot or as a closed finding unit divides the professional public to this day. In my personal opinion, it depends on the circumstances of location and placement, whether the hoard was found by a well, by a wall, etc.

We must also consider the main reason leading to the need to store valuables. Colin Renfrew dealt with the idea of 'value', which could eventually lead to the deposition of hoards. According to Renfrew, the concept of value is created in the human brain, but this would not be possible without any physical experience and knowledge of material properties. ${ }^{16}$ Changes in material culture can be understood as indicators of progress, of societal changes and as a basic part of human nature. This theory is observable throughout the whole history of humankind. We are able to study artefactual changes in hoards through the millennia. Most hoards contain artefacts typical for a particular age or period. Novelties like imports are often found in hoards as they are valuable and less easily attainable.

\section{Hoards of Iron Implements in Slovakia}

In 1986, Andrea Bartošková compiled hoards with iron implements from throughout Slovakia as well as similar types

13 NovotNÝ 1986, 190.

14 FARKAŠ 2001.

15 Eggert 2001, 79.

16 RENFREW 2009, 134. of hoards from former Czechoslovakia. ${ }^{17}$ Subsequently, the evidence from some local sites like Bojná ${ }^{18}$ or Pobe$\operatorname{dim}^{19}$ and other new sites was published. To date, 74 hoards with iron implements from Slovakia have been published. Most of them were already compiled in Bartoškovás publication. A characteristic feature of hoards from Slovakia is the presence of iron tools and other iron objects. We see a large spectrum of artefacts, from agricultural tools, craft tools and household items to a range of weapons or ingots like axe-shaped bars and other implements. Occasionally hoards also contain bronze objects, for example in the case of Moravský Ján, which has been interpreted as proof of contacts with the Avarian Khaganate (see section 4). ${ }^{20}$

The distribution of hoards in Slovakia shows that most are located in the northwestern part, with only some in the southern part. Most were found in the mountains and geographically close to the centres of Great Moravia. ${ }^{21}$ The distribution of hoards with iron implements in Slovakia is shown on the map (see Fig. 1).

Our knowledge of the hoards of Slovakia depends partly on the circumstances of excavation (find circumstances) and their subsequent interpretations. Hoards of iron implements have been discovered in hillforts (fortified strongholds), in features in unfortified settlements and in two cases in the upper part of grave fillings, but most have been found randomly and we lack all further information concerning the find spot and context. Others were excavated many decades ago without proper documentation. In these cases, interpretation is very problematic and we depend entirely on what can be deduced from the artefacts contained in the hoards. This study focuses on published hoards that have been documented, i.e. the type of artefacts, the statement of preservation, the find circumstances, dating, etc. have already been analysed. Unfortunately, a lot of hoards were documented in statements as they were brought to archaeologists or discovered by detectorists, which is forbidden by law in Slovakia.

The hoards are further separated in terms of excavation circumstances and according to the context in which they were found. It was decided to differentiate between unknown (without detailed information), settlement, hillfort (strongholds) and out of the settled area. Hoards that fall into the category of natural context are those that have no connection to a hillfort or settlement, but were, for example,

\footnotetext{
17 BARTošKová 1986.

18 Pieta 2007. - TurČAn 2012.

19 BialeKová 2008.

20 Zа́воJNí́ 2009, 103.

21 See MACHÁČEK 2013.
} 


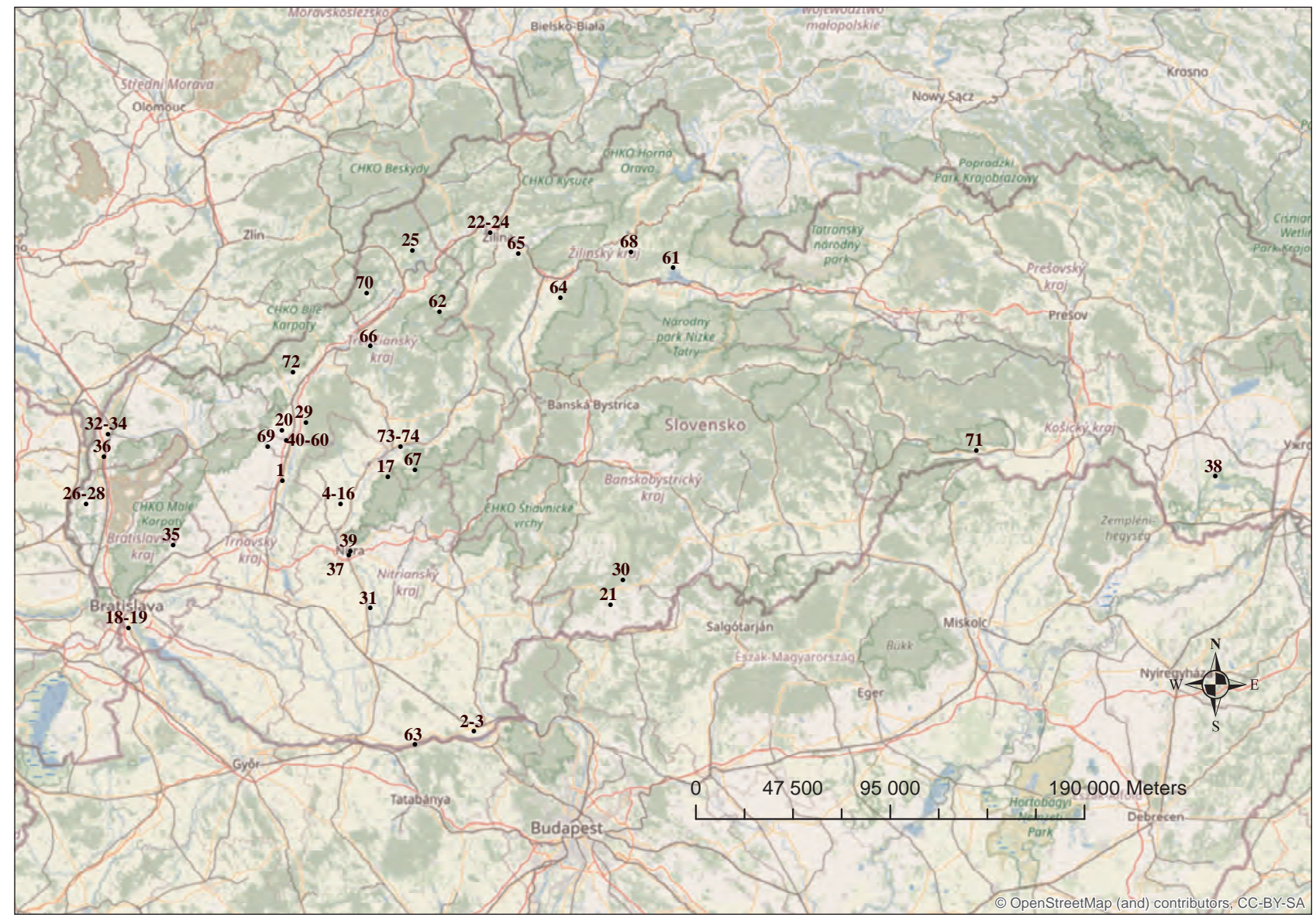

Fig. 1. The distribution of hoards with iron implements in Slovakia. -1. Bašovce. - 2-3. Bíňa I-II. - 4-16. Bojná I-XIII. - 17. Bošany. 18-19. Bratislava I-II. - 20. Čachtice. - 21. Čebovce. - 22-24. Divinka I-III. - 25. Dolná Mariková. - 26-28. Gajary I-III. - 29. Hrádok. 30. Horné Plachtince. - 31. Komjatice. - 32-34. Kúty I-III. - 35. Modra. - 36. Moravský Ján. - 37. Nitra-Šindolka. - 38. Oborín. - 39. Palánok. -40-60. Pobedim I-XXI. - 61. Prosiek. - 62. Pružina. - 63. Radvaň nad Dunajom. - 64. Sklabiňa. - 65. Stráňavy. - 66. Trenčianske Teplice. -67. Velký Klíž. - 68. Vyšný Kubín. - 69. Vrbové. - 70. Vršatské Podhradie. - 71. Zádiel. - 72. Zemianske Podhradie. - 73-74. Žabokreky nad Nitrou I-II (Map: ArcGis Basemap).

found in connection with a river or stream. A further group of hoards, which could be considered as votive hoards, were found in graves. As this group was too small to be used on its own in statistical analysis, it was therefore included into the also relatively small category of natural contexts. With the help of PCA/FA, this study will attempt to recognize the main features which characterize early medieval hoards in Slovakia.

In the process of analysis I created a database which contains published hoards of iron implements from Slovakia. It includes 74 hoards with 41 artefacts, in other words, variables. Because some artefacts only appear in one or only a few cases, such artefacts were combined into logical groups, according to their characteristics or usage. In this paper, data from hoards containing at least two artefacts were used.

\section{Historical Background}

Hoards classified as early medieval here date between the end of the $8^{\text {th }}$ century and the $9^{\text {th }}$ century, occasionally also to the beginning of the $10^{\text {th }}$ century. During this period, southern and parts of western and eastern Slovakia were under the control of the Avarian Khaganate, which disintegrated at the beginning of the $9^{\text {th }}$ century (AD 803).22

The Avarian Khaganate fell as the consequence of the conquests of Charles the Great (Charlemagne), but also due to pressure from the Slavs of the middle Danube, who controlled the Nitra chiefdom on the northern borders of the khaganate. With the collapse of the khaganate, the spotlight shifted to the Nitra chiefdom. The period until the first third of the $9^{\text {th }}$ century saw the appearance of many hillforts.

22 Zа́војNі́к 2009, 17. 
During this time, the whole geopolitical situation in central Europe was changing.

The conqueror of the Nitra chiefdom in 833 was Mojmír I, from the chiefdom of Morava. This led to the establishment of Great Moravia with Nitra remaining an administrative centre until AD 1110/1113, during the Arpad dynasty of the Hungarian kingdom. ${ }^{23}$ After Great Moravia had been established, a phase of new central hillfort settlements such as at Mikulčice and Staré Město u Uherského Hradište followed, which also saw the renewal of the Nitra hillfort. $^{24}$

Practically throughout its whole existence, Great Moravia was at war with the Frankish Empire, which regarded the Great Moravian area as its own. They demonstrated their claim on this territory through numerous military actions as well as in political relations. The influence and power of the Frankish kings in internal political issues can be seen in the dethroning of Mojmír I (conqueror and first ruler of Great Moravia between 833 and 846) and the enthronement of his nephew Rastislav I (846-870) as the new chief of Great Moravia. ${ }^{25}$ The latter was later dethroned by his nephew Svätopluk, with the help of the East Frankish prince Carloman of Bavaria. ${ }^{26}$

Svätopluk's reign is known as an epoch of large-scale expansion of Great Moravian land to the north and to the east to the river Tisa. His ambitions also led him into the areas of the Eastern Mark and Pannonia. ${ }^{27}$ After Svätopluk's death in 894, the gradual decline of Great Moravia began. The whole chiefdom was weakened by internal political conflicts between Svätopluk's sons Mojmír II and Svätopluk II and by attacks from Hungarian tribes. ${ }^{28}$ However, a range of other factors also contributed to the fall of Great Moravia, including economic factors and environmental changes. ${ }^{29}$

An interesting situation can be observed with the Great Moravian centres of Pohansko, Mikulčice and Staré Město u Uherského Hradište in the Czech Republic, which fell with Great Moravia and were not rebuilt by the Přemysl dynasty. This is unusual in comparison to Great Moravian hillforts in Slovakia, as most of those were not destroyed and survived the fall of Great Moravia, which, as Tatiana Štefanovičová suggests, may have been due to agreements between local and Hungarian chiefs. ${ }^{30}$

23 STEINHÜBEL 2004, 327.

24 Beranová 1988, 146.

25 Múcska, Daniš, ŠEvČíková 2006, 85.

26 STEINhÜBEL 2004, 127-128.

27 STEINHÜBEL 2004, 138-139.

28 KouřIL 2016, 109, 110-124.

29 ŠTEFAN 2011, 334-335.

30 ŠTEFANOVIČOVÁ 2008, 139-141.

\section{Principal Component Analysis (Factor Analysis)}

In general, using statistics in archaeology means looking for regularities in time and in space. Statistics are used for work with a large or huge amount of direct data. They are used for testing hypotheses. I decided to use PCA/FA for finding commonalities between artefacts found in early medieval hoards and iron implements from Slovakia.

Two types of dimensional analysis are commonly used in archaeology: principal component analysis and the closely related factor analysis. PCA/FA is an explorative statistical method; it creates more factors-structures. In archaeology, factor analysis has been used by the pioneer of processual archaeology Lewis R. Binford since the 1960s as a new method for classifying artefacts. ${ }^{31}$

Principal component analysis and factor analysis are generic names given to a class of multivariate approaches used to quantify the structure underlying data matrices. They both seek to define a set of common underlying dimensions that structure the data. These methods are effectively exploratory data analyses, in that they do not explicitly evaluate previously defined null hypotheses. Instead, they look at shared variation among a set of variables that can be mathematically modelled. They then produce a measure of the amount of shared variation that can be tied to hypotheses of interest given an appropriate analytic and theoretical structure, but that are not formal statistical tests in and of themselves. PCA and FA are closely related means of identifying 'new' dimensions that capture the essence of the correspondence among the original variables. ${ }^{32}$

PCA/FA uses an orthogonal transformation to convert a set of observations of possibly correlated variables into a set of values of linearly uncorrelated variables called principal components in groups called factors. The number of principal components is less than or equal to the number of original variables. This transformation is defined in such a way that the first principal component has the largest possible variance (that is, it accounts for as much of the variability in the data as possible), and each succeeding component in turn has the highest variance possible under the constraint that it is orthogonal to the preceding components. The resulting vectors are an uncorrelated orthogonal basis set. PCA/FA is sensitive to the relative scaling of the original variables. ${ }^{33}$

PCA/FA is one of the basic methods for compressing data: from the original number of variables $(n)$ it can compress to a representative of variables $(m)$ and thus we are

\footnotetext{
31 Binford 1962, 218-220.

32 VANPoOL, LeONARd 2011, 286.

33 WeBER 1997, 203.
} 
able to explain enough of the variabilities from the basic database. The system of newly created variables (principal components) contains linear combinations from the original variabilities. The first component is the biggest and represents the biggest part of the database; the others have smaller values and they contribute to a cumulative picture of variance. ${ }^{34}$

Mechanically, factor analysis and principal component analysis both allow variance maximizing rotation (VARIMAX), a fancy way of saying that they allow the data to be structured around the components that explain the most variation. In truth, variance maximization rotation (VARIMAX) in principal component analysis is not really part of the method but is based on a 'borrowing' of the technique from factor analysis. ${ }^{35}$

PCA/FA was undertaken using IBM SPSS Statistic 24 with Varimax rotation, which minimizes the number of variables and defines the largest variance, thus creating simple structures. The possible values are between -1 and 1 , whereby 1 indicates the highest possible correlation of variables, 0 means there is no observable correlation, and -1 means the mutual exclusion of variables. ${ }^{36}$

\section{The Database}

The database used in this study consists of 74 hoards of iron implements, which includes simpler hoards with only one kind of artefact and more complex hoards with more than one type. An artefact is a variable or descriptor of the hoard, which defines the hoard itself. The sites where these hoards were found are contexts. Some rare variables/descriptors have to be included in other groups of variables. ${ }^{37}$ The database contains rows - the hoards (objects) themselves, like the name of the site - and columns - the artefacts, which were found in the hoard (variables). This version of the database is a binary matrix. This means that the focus is on the presence (1) or absence ( 0 ) of the artefacts.

The database (or descriptive matrix) contains 11 variables and groups of variables. The independent variables are sickles, ploughshares, coulters, scythes and axe-shaped bars. They were left as they are, because they appear in more than $25 \%$ of the hoards. Some variables had to be put into the groups of variables. Todd L. VanPool and Robert D. Leonard state that "[i]f the researcher wishes to evaluate some proposed structure that may characterize the data, then the

\footnotetext{
34 Mazuch, Hladík, Skopal 2017, 223.

35 JollifFe 2002, 166.

36 Weber 1997, 203. - NeustupnÝ 2007, 142-143.

37 NeustupnÝ 1997, 237-238.
}

pertinent variables should be included." ${ }^{38}$ However, the inclusion of additional variables increases the likelihood of including variables that do not meaningfully correspond with any other variables, meaning that the principal component or factor analysis will not provide useful data reduction for them. The groups are blacksmiths' tools (Blacksm_tools: tongs, hammers, anvils, files, borers etc.), woodworking tools (spikes, drawknives, linchpins, saws, chisels), weapons (swords, lance heads, arrow heads), other small agricultural tools (Other_agr_tool: spuds, drawshares, hoes, shares), equestrian equipment (E_equip: spurs, stirrups, mountings, snaffles) and household tools (Househ_tool: bucket parts, knives, scissors, keys, cauldrons, Silesian basins). Using the application Compute Variable, weapons and equestrian equipment were computed together and the category warriors' equipment (War_equip) was created.

Factors are here defined as groups of principal components that were determined to characterize hoards. The created factors will be compared with the find circumstances, which means hillfort (fortified settlement), settlement (unfortified settlement), outside the settled area (graveyard, natural environment) and unknown find circumstances.

\section{Results}

The principal component analysis generated a correlation matrix (Tab. 1) which shows correlations between the variables. The base value is 1 , which is the maximum possible value. This value can be achieved by every variable when correlated just with itself. When comparing the correlation of one direct variable with others, the value is in general approximately \pm 0.5 . For example, the ploughshare has a maximum value with itself, but the second largest value, 0.712 , which is understood as a high correlation, is with Other_agr_tool. This value means that the probability of a ploughshare and other small agricultural tools (Other_agr_tool) appearing together is more than $70 \%$.

At the other end of the spectrum, the lowest value between variables can be seen in the correlation between the group warriors' equipment (War_equip) and axes, which is 0.095 . This shows that warrior equipment and axes almost never appear together in one hoard, which proves that axes were mostly used as crafting tools and not as weapons. The highest negative values indicate common elimination variables (mutually exclusive variables) in one specific hoard. This common elimination is, for example, noticeable between household tools (Househ_tool) and axe-shaped bars: -0.412 .

38 VanPool, Leonard 2011, 292-293. 


\begin{tabular}{|l|c|c|c|c|c|c|c|c|c|c|c|}
\hline Correlation & $\begin{array}{c}\text { Axe- } \\
\text { shaped bar }\end{array}$ & $\begin{array}{c}\text { Plough- } \\
\text { share }\end{array}$ & Coulter & Sickle & Scythe & Axe & $\begin{array}{c}\text { Other_ } \\
\text { agr_tool }\end{array}$ & $\begin{array}{c}\text { Blacksm__ } \\
\text { tools }\end{array}$ & $\begin{array}{c}\text { Househ_- } \\
\text { tool }\end{array}$ & $\begin{array}{c}\text { Woodw_- } \\
\text { tool }\end{array}$ & $\begin{array}{c}\text { War_ } \\
\text { equip }\end{array}$ \\
\hline Axe-shaped bar & 1.000 & -.224 & -.141 & -.45 & -.140 & -.127 & -.288 & -.097 & -.412 & -.023 & -.359 \\
\hline Ploughshare & -.224 & 1.000 & .598 & .324 & .572 & .341 & .712 & .307 & .327 & .459 & .168 \\
\hline Coulter & -.141 & .598 & 1.000 & .298 & .478 & .402 & .480 & .516 & .303 & .365 & .217 \\
\hline Sickle & -.455 & .324 & .298 & 1.000 & .408 & .189 & .338 & .229 & .507 & .375 & .212 \\
\hline Scythe & -.140 & .572 & .478 & .408 & 1.000 & .351 & .502 & .233 & .387 & .413 & .372 \\
\hline Axe & -.127 & .341 & .402 & .189 & .351 & 1.000 & .394 & .569 & .386 & .473 & .095 \\
\hline Other_agr_tool & -.288 & .712 & .480 & .338 & .502 & .394 & 1.000 & .363 & .253 & .363 & .165 \\
\hline Blacksm_tools & -.097 & .307 & .516 & .229 & .233 & .569 & .363 & 1.000 & .423 & .535 & .238 \\
\hline Househ_tool & -.412 & .327 & .303 & .507 & .387 & .386 & .253 & .423 & 1.000 & .349 & .464 \\
\hline Woodw_tool & -.023 & .459 & .365 & .375 & .413 & .473 & .363 & .535 & .349 & 1.000 & .238 \\
\hline War_equip & -.359 & .168 & .217 & .212 & .372 & .095 & .165 & .238 & .464 & .238 & 1.000 \\
\hline
\end{tabular}

Tab. 1. The correlation matrix shows correlations between the variables. The value between -1 and 1 presents the correlation between every single artefact or groups of artefacts (for example Other_agr_tool and axe-shaped bars).

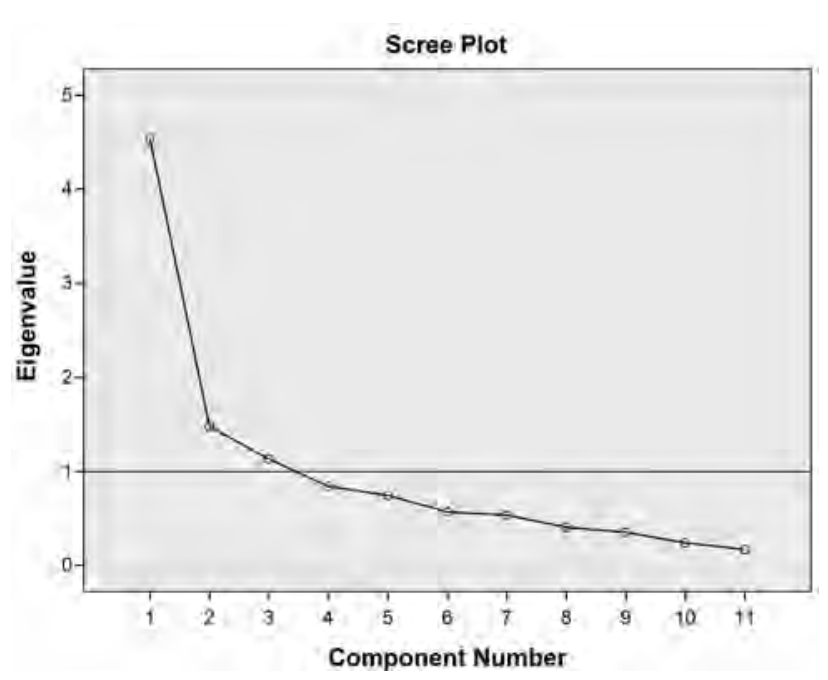

Fig. 2. The scree plot shows all 11 variables/components decreasing from the highest to the lowest value. The three highest variables are above 1 and the fourth is already below.

The scree plot shows all 11 variables/components decreasing from the highest to the lowest value (Fig. 2). The three highest variables are above 1 and the fourth is already below it (Graph 1). These three variables were selected for another part of PCA/FA where they were rotated by Varimax rotation and extracted as three factors (groups of components), which characterize hoarding in Slovakia (Tab. 2). Every factor is created from several variables with the highest factor coefficients or correlations (values closest to 1). The first factor comprises agricultural tools, the second craft

\begin{tabular}{|l|c|c|c|}
\hline & 1 & 2 & 3 \\
\hline Ploughshare & .875 & .192 & .120 \\
\hline Other_agr_tool & .823 & .179 & .139 \\
\hline Scythe & .676 & .210 & .293 \\
\hline Coulter & .627 & .432 & \\
\hline Blacksm_tools & .145 & .853 & .143 \\
\hline Axe & .249 & .754 & \\
\hline Woodw_tool & .330 & .683 & .132 \\
\hline Axe-shaped bar & -.171 & .143 & -.781 \\
\hline Househ_tool & .108 & .429 & .724 \\
\hline War_equip & & .187 & .688 \\
\hline Sickle & .351 & .107 & .637 \\
\hline
\end{tabular}

Extraction Method: Principal Component Analysis.

Rotation Method: Varimax with Kaiser Normalization (rotation converged in 6 iterations).

Tab. 2. Rotated component matrix with three principal components: $1^{\text {st }}$ factor with agricultural tools, $2^{\text {nd }}$ factor with craft tools and $3^{\text {rd }}$ bipolar factor with household tools, warriors' equipment and sickles vs. axe-shaped bars.

tools, the third is the bipolar factor. Every site also has a factor score typical for the direct factor with principal components. The factor score represents a value, and for every site and every hoard this value is the highest only for one 
factor, while for the others it is low. For example, the hoard from Čebovce (21) is typical for the factor with agricultural tools; it has the highest factor score for this factor.

\subsection{Agricultural Tools}

The first factor is made up of only agricultural tools, which have the highest factor coefficient (Tab. 2). The direct artefacts within this factor are ploughshares (0.875), coulters (0.627), scythes (0.676), and other small agricultural tools (Other_agr_tool) like drawshares, shares, spuds, hoes, mattocks (0.823). These kinds of tools are most commonly found in hoards with iron implements from Slovakia. After generating factor coefficients in the descriptive matrix, every site (hoard) also has a factor score typical for the direct factor. The highest factor scores were observed in hoards from Čebovce (21), Bratislava II (19), Divinka II (23), Bojná X (13), Vršatské Podhradie (70), Žabokreky nad Nitrou II (74), Palánok (39) and Gajary III (28). Common features of these hoards, aside from their high values, are also the variety and number of artefacts within the hoards.

The excavation circumstances (Fig. 3) are mostly unknown and only a minority of hoards were found in early medieval settlements. The connection of hoards with agricultural tools is understandable, as agricultural production was also concentrated around settlements. On the other hand, only a few hoards containing agricultural tools were found in hillforts.

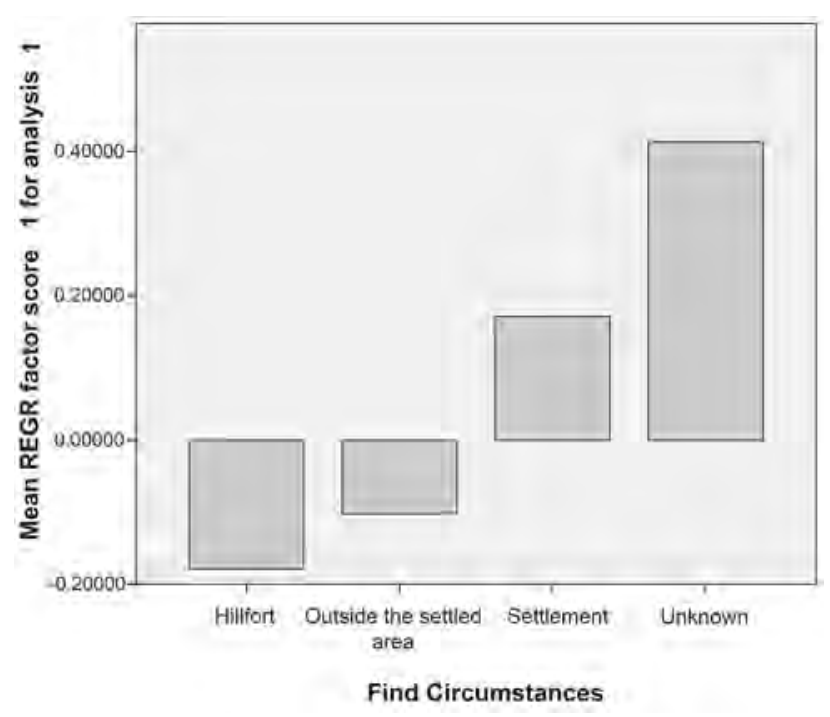

Fig. 3. Factor 1: Agricultural tools and find circumstances.

\subsection{Craft Tools}

The second most common factor is represented by craft tools, including blacksmiths' tools (Blacksm_tools) like hammers, spikes, wimbles, tongs etc. (0.853); axes (0.754) and woodworking tools (Woodw_tool) like spikes, drawknives, linchpins, saws, chisels (0.683) (Tab. 2). Hoards with the highest factor score in this factor are Horné Plachtince (30), Pružina (62, Fig. 4) and Zemianske Podhradie (72). Similarly to what was observed in the first factor, a commonality amongst hoards with a high factor coefficient of craft tools is the number of this type of artefact in these hoards.

The excavation circumstances are also similar to those for the previous factor (Fig. 5). Most hoards of this factor were found without any detailed contextual information, the circumstances being unknown. However, a connection between craft tools and the location of hoards outside the settled area can be established. The hillforts and settlements are mutually exclusive with unknown and out of the settled area; in other words, this factor was not found in settlements or hillforts.

\subsection{Bipolar Factor}

The bipolar factor presents four kinds of artefacts: axeshaped bars (-0.781); household tools (Househ_tool) like keys, scissors, bucket parts, cauldron, knives and Silesian basins (0.724); warriors' equipment (War_equip) containing weapons like lance heads, swords and arrow heads as well as equestrian equipment like mountings, spurs, snaffles and stirrups (0.688), and sickles (0.637). The bipolar factor indicates the mutual exclusion of axe-shaped bars and household tools, warriors' equipment and sickles. The bipolar factor represents two structures. The first represents the combination of household tools, warriors' equipment and sickles, which appear together in one hoard. The second represents axe-shaped bars, which reflect negative values and common elimination from other variables (Fig. 4). Mostly they constitute the only artefact in a hoard and are not hoarded with other artefacts or groups of artefacts. Interestingly, the number of hoards only containing axeshaped bars and no other artefacts is quite high. Examples include most hoards from Pobedim I, IV-XXI (41, 44-61) and some hoards from Bojná I, VI-VIII, XII, XIII (4, 9-11, $15,16)$ and Bína I, II (2-3). The hoards with the highest positive factor score include Bojná V (5), Bojná XI (14), Kúty I (32), Gajary II (27), Horné Plachtince (30), etc. These hoards also have in common a quite low variation of contents and, in general, a small number of artefacts.

Moreover, this mutual exclusion is also reflected in the excavation circumstances, with a contrast between settlements, hillforts and unknown and natural contexts (Fig. 6). 


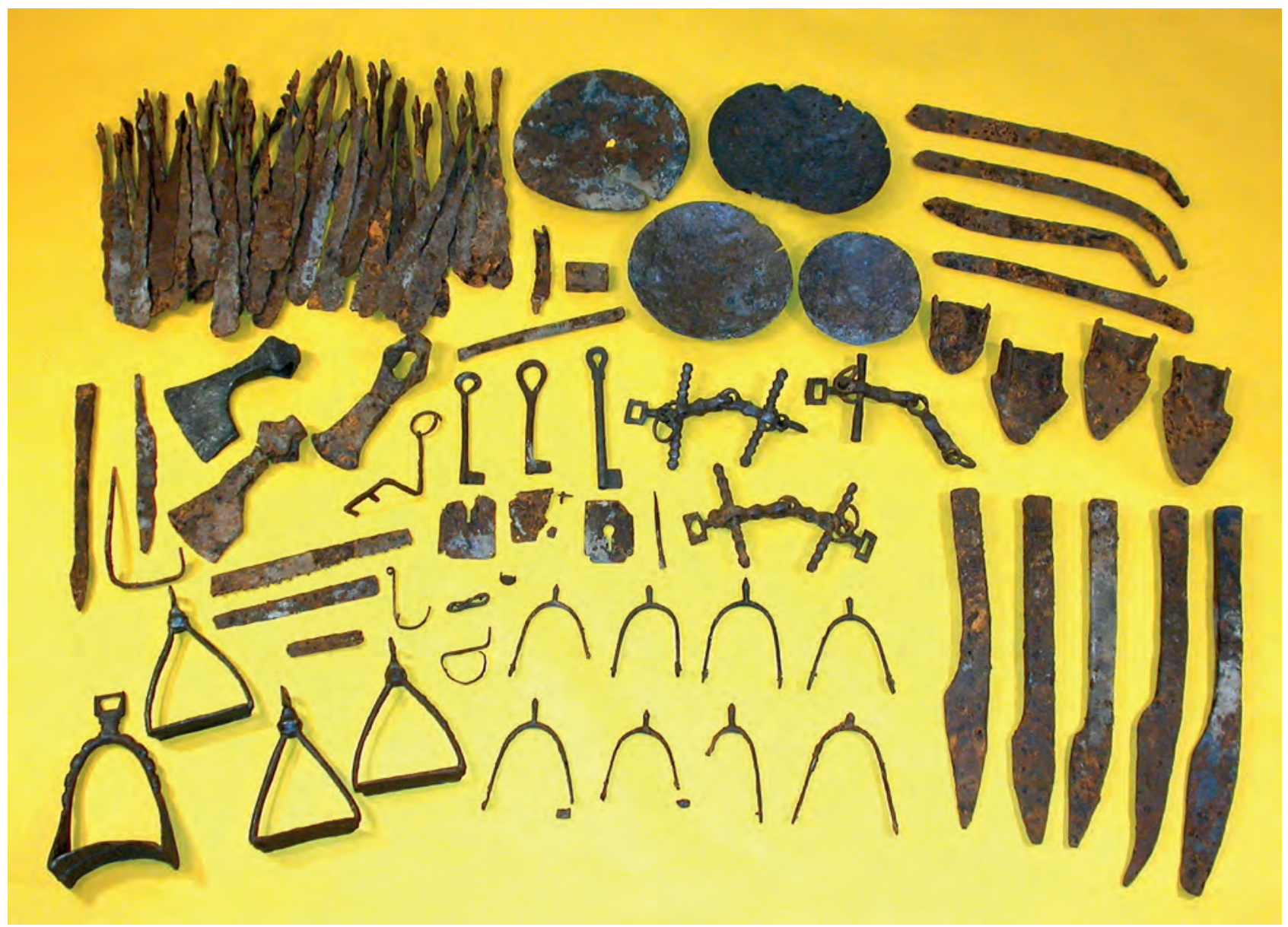

Fig. 4. Hoard with iron implements from Pružina (Photo: K. Pieta, Archaeological Institute at Slovak Academy of Sciences in Nitra, 2008).

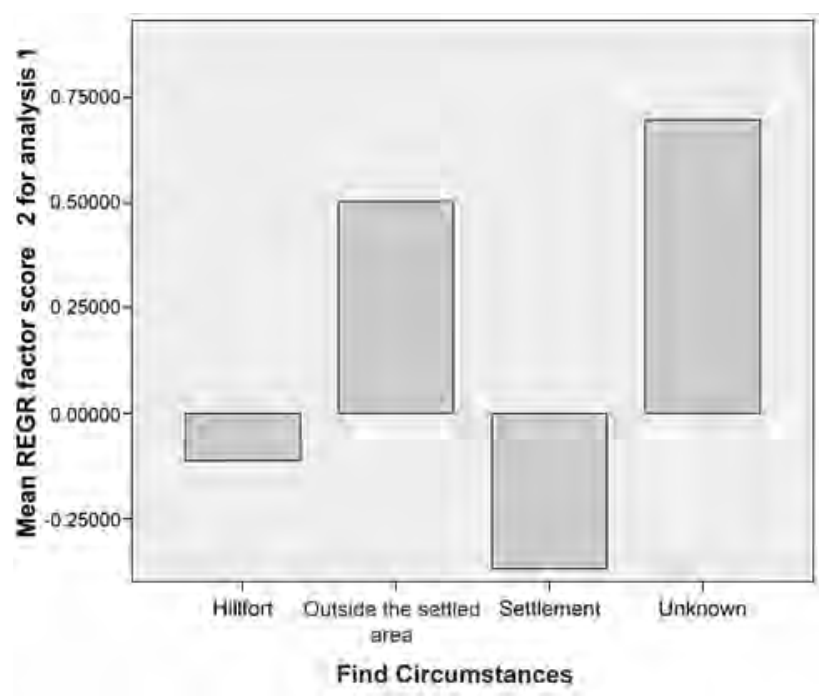

Fig. 5. Factor 2: Craft tools and find circumstances.

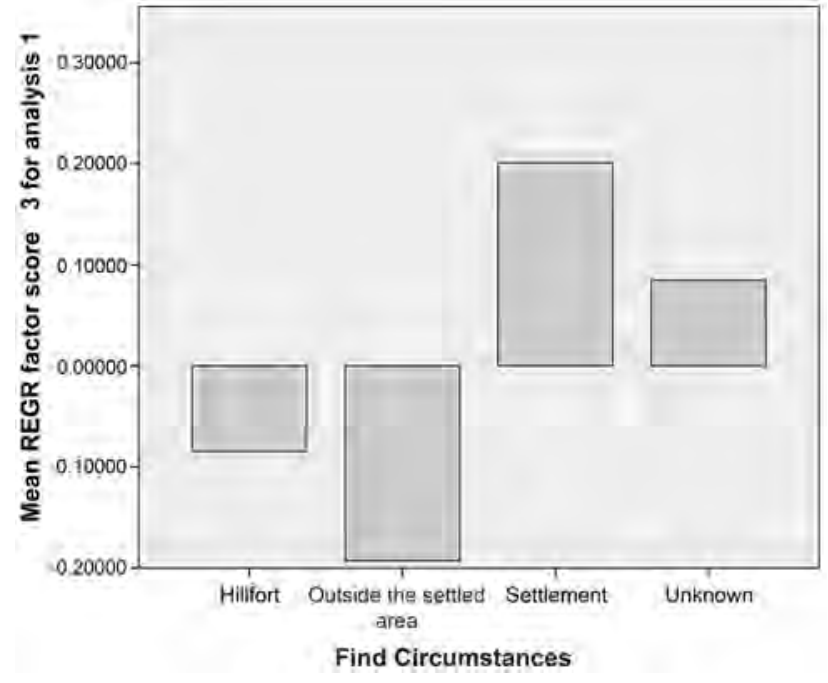

Fig. 6. Factor 3, bipolar factor: household tools, warriors' equipment and sickles (positive values) vs. axe-shaped bars (negative values) and find circumstances. 
Household tools, warriors' equipment and sickles are part of hoards in settlements, out of the settled area and with unknown circumstances, and to some extent at hillforts, whereas axe-shaped bars occur in hoards found in hillforts and two were found in graveyards.

\section{Interpretations: The Results of Principal Component Analysis/Factor Analysis}

PCA/FA generates three main factors, which show us the most deposited tools or groups of tools. Two of them show us two types of tools. The first is represented by the agricultural tools, three of which were used for the cultivation of fields and preparing the soil for seeding (ploughshare, coulter, Small_agr_tool: drawshares, shares, spuds, hoes, mattock). Only one (scythe) is a tool for scything, from which it can be understood that the main use was for harvesting. The second factor contains tools which could be characterized as craft tools (Blacksm_tools: hammers, spikes, wimbles, tongs, etc.; Woodw_tool: spikes, drawknives, linchpins, saws, chisels; axes).

At a first glance at the tools, we are dealing with common, everyday tools, but it shows us some form of dependence between humans and things. According to Ian Hodder, there are two forms of dependence. Humans use the things that allow humans to be, live, socialize, eat and think. The second form of dependency involves some form of constraint. Human beings depend on things, both in the sense of relying on things and in the sense of being contingent on the particular things relied upon. Sometimes humans seem to reflect on their dependence on things, and at other times they seem hardly aware of it and take them for granted..$^{39}$

This kind of dependency can also be explained by Renfrew's theory of cultural systems. Renfrew created a theory of systems, subsystems and feedbacks as a reaction to what comes into the system and what goes out. The cultural system is defined by several subsystems: the subsistence subsystem, the technological subsystem, the social subsystem, the projective or symbolic subsystem and the trade and communication subsystem. ${ }^{40}$ The feedback occurs between the subsystems. It is a reaction to changes in subsystems. Positive feedback leads to an upgrading and creates an exponential rise or fall. Negative feedback has a tendency to bring stability and preservation. ${ }^{41}$

The domination of agricultural tools and craft tools in hoards could be understood as the effort of bringing stability during the collapse of the first two subsystems: the

\footnotetext{
39 HODDER 2017, 17-19.

40 RENFREW 1972, 22-23.

41 RENFREW 1972, 36-37.
}

subsistence subsystem and the technological subsystem. The subsistence subsystem means actions which are related to the distribution of food resources. The human being and the food resources and food units themselves are components of the subsystem which are interrelated by these specifically subsistence-oriented activities. The technological subsystem means human activities which result in the production of material artefacts. The components are the men, the material resources and the finished artefacts. ${ }^{42}$ Without agricultural tools, the soil cannot be properly prepared for seeding, which has an impact on food production. Human beings were dependent on the agricultural tools. For example, without the ploughshare and coulter, there could be no stump jumper. Without blacksmiths' tools, the smith could not work with iron and would be unable to create or repair other kinds of tools as needed.

The bipolar factor contains two structures: axe-shaped bars and, on the other hand, warriors' equipment (War_ equip: weapons: lance heads, swords, arrow heads, and equestrian equipment: mountings, spurs, snaffles, stirrups), household tools (Househ_tool: keys, scissors, bucket parts, cauldron, knives, Silesian basins) and sickles. Warriors' equipment and household tools are also found at settlements and at hillforts. It can be understood as part of the estate of bands of warriors at the hillforts. On the other hand, based on finds of weapons at the settlements, Ivo Štefan also assumes bands of warriors within the settlements, the socalled Banernkrieger. ${ }^{43}$

It is interesting that there is a common exclusion between axe-shaped bars and sickles. The sickle is primarily used for harvesting, but in early medieval times was also put into graves. According to Zuzana Borzová, the sickle in early medieval graves can have several meanings. It can be intended to point to the status of an individual in the grave as a peasant or farmer; it can also have a magical-ritual meaning, or, together with household tools and weapons, can point to the warrior status of the interred. Most of the graves with household tools, weapons and sickles were those of males and dated to the Avar Khaganate and Great Moravian period. ${ }^{44}$ The factor combining household tools, warrior equipment and sickles could also be understood that way, namely that hoards with these three components may have belonged to the property of a warrior, but may also have some magical-ritual meaning. Where the hoard was discovered outside the settled area, this can also have similar implications.

42 RENFREW 1972, 22.

43 ŠTEFAn 2011, 337-338.

44 Borzová 2006, 210-211, 216-217. 
The problem of axe-shaped bars remains unsolved. Especially in Slovakia, they are found in hoards at hillforts, but they were also discovered at settlements or graveyards (outside the settled area). The exact position in the hillfort, settlement or graveyard could be understood as some orientation point for future recovery. If the hillforts were interpreted as the centre of power and craft, the huge concentration of axe-shaped bars has to have a different meaning. Specific places where hoards with axe-shaped bars were found are walls close to the gates of hillforts. These places could be understood as orientation points meant to facilitate the later recovery of the hidden objects. These were intended not just as a source of iron, as an ingot, but maybe also as a tool to be exchanged for other items. This view can be countered by the question of why they are concentrated only in the central part of central Europe, mostly in the area of foreign Great Moravia. In general, the hoards with axeshaped bars are dated to the $9^{\text {th }}$ century or to the first half of the $9^{\text {th }}$ century. ${ }^{45}$ This is supported by cases such as the Pobedim hillfort, where numerous hoards with axe-shaped bars and equestrian equipment were found to have been hidden in the context of the hillfort's collapse. New dendrochronological data from Pobedim have yielded new information about activities in the Pobedim hillfort, where building activity by the walls was renewed at the end of $9^{\text {th }}$ century. The same situation was also identified in Bojná. ${ }^{46}$ Because of this dendrochronological data, it is possible that the dating of the hoards with iron implements in Pobedim, and possibly in Bojná too, needs to be moved to end of the $9^{\text {th }}$ century, to the time of the fall of Great Moravia.

The economy of Great Moravia was not on the high level of empires such as the Frankish Empire or the Byzantine Empire. It was based on the economy of pre-state organizations. ${ }^{47}$ In the first stages of organization as a state, the leader had to secure and continually strengthen loyalty to him and reinforce his legitimacy. The legitimacy of the ruler is the belief held by the elites and the population that the ruler is a proper and legitimate ruler, and this legitimacy passes to his decisions or to the government system. If support falls below the necessary threshold, it leads to a fall. ${ }^{48}$ Hoards with axe-shaped bars were mostly found at hillforts, which were the domain of local chiefs. They could be used as some kind of gift from the leader to his subjects, minor or local chiefs. Occasionally axe-shaped bars and warriors' equipment are found in one hoard.

45 Bialeková 2008.

46 Henning et al. 2015, 340-342. - Bialeková 2017, 12-13.

47 SMITH 2004, 78-79.

48 TAInTER 2009, 44.
According to Jiří Macháček, the Great Moravian economy was based on the power of the leader, who was the 'contact person' on the Great Moravian side. The leader of Great Moravia established and coordinated the market; in known sources it is called the 'Moravian market'. Sources suggest that this leader played a central role in the trade network as the primary (possibly even the only) figure controlling the flow of foreign goods into the country. ${ }^{49}$ In the inner market of Great Moravia, axe-shaped bars could be used on the basis of the 'Gewichtsgeldwirtschaft' and the coin-based financial system. In the coin system, the total value is represented in one single coin, while the system of Gewichtsgeldwirtschaft is based on the standard value and the weight of the metal accepted in the area. The origins of this system, however, extend to the Muslim Caliphate, where a standard metal weight system was used. ${ }^{50}$

The hoards with axe-shaped bars could be understood through comparison with early medieval hack-silver hoards (Hacksilberbortfunde). The hiding of hack-silver hoards is probably related to the transition from pre-state societies (chiefdoms) to the first state organizations. Areas that did not benefit economically from their own natural resources were reliant on other means of generating wealth, which mainly involved plundering and redistributing goods. ${ }^{51}$ According to Przemysław Urbanczky, in connection with fragmented silver depots, they primarily served as a donation to gain political loyalty and thus later to the voluntarily supply of the necessary food, such as grain and meat. Silver was not given simply as the daily rate for warriors, but as a reward for participation in a joint military campaign and in the hope of securing military support for the next expedition. Hiding of it can be seen as a kind of response to the economic situation or storage of a dowry. It could also have been a simple way of securing the sum needed for some important transaction, of setting aside provisions for hard times, or a means of fulfilling the very need of amassing a fortune. ${ }^{52}$ On the other hand, the elite of Great Moravia was well known for its jewellery and artefacts made from silver, gold and bronze. Nevertheless, only a few bronze artefacts were put into the hoards. The value of iron dominates.

\section{Conclusion}

With the help of the statistical method principal component analysis, it was possible to isolate primary basic factors (groups of principal components) which characterize

\footnotetext{
49 MACHÁČEK 2015, 472-473.

50 KilgER 2011, 264-265.

51 URBANCZYK 2009, 501-502.

52 URBANCZYK 2009, 506-508.
} 
Slovak hoards of iron implements from the early medieval period. Resulting factors were determined by artefacts, which, together with the hoards' other properties and the excavation circumstances, provide a more complete picture of the phenomenon of hoards. The factors were agricultural tools, craft tools and the bipolar factor. Every factor was found to have typical excavation circumstances according to which they could be linked with settlements, hillforts, areas outside the settled area (natural environments, graveyards) and unknown circumstances.

Hoards with iron implements were found to be concentrated in the western and particularly the northwestern part of Slovakia, close to the centres of Great Moravia. These hoards are generally dated to the $9^{\text {th }}$ century, but could possibly be even more precisely assigned to the middle part of the $9^{\text {th }}$ century, due to the unrest caused by Mojmír I's conquests during this time. Some of the hoards were dated to the transition from the $9^{\text {th }}$ to the $10^{\text {th }}$ century.

The reasons and motivations people may have had for burying hoards and hiding their fortunes were also addressed. It was suggested that these may have been related to religion or fear in dangerous times. One possibility could be that the survival of the people depended on these tools. Without agricultural tools, they were not able to cultivate land; without cultivated land, there was no harvest and no possibility to provide food. It is not possible to ascertain with certainty whether or not the tools were used in every case.

Hoards of iron implements are not usually hidden in a box or any other type of case. Only a few of the hoards were hidden in this way. For example, the hoard from Moravský Ján (36) was hidden in a cauldron..$^{53}$ Accordingly, it is possible to hypothesize some intention to preserve the tools for the future.

The presence of weapons and warriors' equipment in hoards is particularly interesting as it is uncommon and begs the question of why a warrior's essential equipment would be buried in a hoard. Compared to the finds of sickles and household tools, which were also found in settlements and graves from the Great Moravian period, this type of equipment is a status symbol indicating class or dignity. ${ }^{54} \mathrm{We}$ can also consider some ritual meaning of hoarding or the hoarded property of a warrior. According to Hans Peter Hahn, the real value of artefacts can lie in their symbolical value.

53 ZавOJNÍK 2009, 103

54 SeE Hanuliak 2004.
The symbolical value is many times more significant than the real value of iron. ${ }^{55}$

Similarly, agricultural and craft tools are a further necessity, without which humankind could not survive. But Hahn refers to these kinds of tools as temporary objects ('Übergangsobjekte'). They may be single everyday tools, which create stable relations in society, and private personal things, which make human beings the way they are. ${ }^{56}$ Similarly, in the present era, we often put some money aside in case of unexpected expenses or 'just in case'. So the difference between 'them' and 'us' is not so great. We save money and, on many occasions, we save precious items after the demise of our grandparents or great-grandparents just because of their symbolic or emotional meaning to us, which no one else can understand.

Inevitably, the results of this study lead to the need for a closer examination of why hoards were buried, why particular locations were chosen and why they contained specific artefacts and combinations of artefacts. We will never be able to see into the head of early medieval people or to understand why they did this or that.

Early medieval hoarding could be a consequence of many other factors: civil war between two sons of Svätopluk, the violent situation on the borders with the Frankish Empire or Magyar tribes on the other part. Hoards could be understood as a negative feedback resulting from changes in the system, which led to the fall of the system or its indefensibility, as happened during the fall of Great Moravia. These hoarded artefacts could represent some kind of hope: when this catastrophe has passed, we can start all over again.

55 HaHn 2015, 13.

56 Hahn 2015, 10-11. 


\section{Appendix 1.}

Catalogue of sites with iron implements in Slovakia. For a map showing all sites see Figure 1.

\section{Archaeological site}

a. Administrative department

b. Circumstances of discovery

c. Artefacts

d. Reference

\section{Bašovce}

a. Trnava district.

b. Settlement.

c. 4 axe-shaped bars.

d. Bialeková 1990, 111.

\section{Bíňa I.}

a. Nitra district.

b. Superposition above the grave.

c. 101 axe-shaped bars.

d. Bialeková 1990, 109.

\section{Bíňa II.}

a. Nitra district.

b. Settlement, under millstone.

c. 60 axe-shaped bars.

d. TuRČAn 2012, 22-24.

\section{Bojná I.}

a. Nitra district.

b. Western part of hillfort.

c. 15 axe-shaped bars, 1 coulter.

d. Pieta, Ruttkay 2007, 35.

\section{Bojná II.}

a. Nitra district.

b. Western part of hillfort.

c. 1 sickle, 6 parts of buckets, 2 fragments of spurs, 1 belt mounting,

2 knives, fragments of iron, 2 spikes, 1 flax napper.

d. Pieta, Ruttkay 2007, 35.

\section{Bojná III.}

a. Nitra district.

b. Southern part of hillfort.

c. 5 spurs.

d. Pieta, Ruttkay 2007, 35.

\section{Bojná IV.}

a. Nitra district.

b. Hillfort.

c. 1 sickle knife, 1 knife, 1 graving knife, 2 axe-shaped bars.

d. Pieta, Ruttkay 2007, 31-35.

\section{Bojná V.}

a. Nitra district.

b. By the wall of hillfort.

c. 3 deformed sickles, 1 saw, 1 part of an axe, 1 bucket holder, fragment of 1 knife, 2 axe-shaped bars.

d. Pieta, Ruttkay 2007, 35.

\section{Bojná VI.}

a. Nitra district.

b. Part of hillfort known as Bojná III.

c. 94 axe-shaped bars.

d. Bialeková, Kamhalová 2000, 34. - Pieta 2007, 15.

\section{Bojná VII.}

a. Nitra district.

b. South wall of hillfort.

c. 32 axe-shaped bars.

d. ŠALKOvSKÝ 2002, 172-173.

\section{Bojná VIII}

a. Nitra district.

b. Hillfort.

c. 202 axe-shaped bars.

d. TuRČAN 2012, 16-21.

\section{Bojná IX.}

a. Nitra district.

b. Hillfort.

c. 1 ploughshare, 2 hoes, 2 spuds, 2 borers, 1 spike chopper, 16 arrow heads, 4 sickles, 2 knifes, 2 coulters, 2 bucket holders, 1 bucket band. d. TuRČAN 2012, 21-22.

\section{Bojná X.}

a. Nitra district.

b. Hillfort.

c. 53 axe-shaped bars, 3 coulters, 3 ploughshares, 3 sickles, 2 hoes, 2 drawknifes.

d. TurČAn 2012, 22-23.

\section{Bojná XI.}

a. Nitra district.

b. Hillfort.

c. 3 ploughshares, 1 scythe, 3 fragments of sickles, 1 linchpin, 2 bucket holders, 1 iron circle, 1 terret, 1 mounting, 1 fragment of spur.

d. TuRČAn 2012, 23-24.

\section{Bojná XII.}

a. Nitra district.

b. By the southern wall of hillfort.

c. 23 axe-shaped bars.

d. ŠALKOVSKÝ 2002, 172-173.

\section{Bojná XIII}

a. Nitra district.

b. Middle part of hillfort.

c. 4 axe-shaped bars.

d. ŠALKOvSKÝ 2002, 172-173.

\section{Bošany}

a. Trenčín district.

b. Unknown.

c. 15 axe-shaped bars.

d. Bialeková 1990, 109. 


\section{Bratislava I.}

a. Bratislava district.

b. Settlement.

c. 13 axe-shaped bars.

d. Bialeková 1990, 110.

\section{Bratislava II.}

a. Bratislava district.

b. Hillfort.

c. Ploughshare, coulter, sickle, hoe, borer, axe, small mattock.

d. Kováč 2013, 100-102.

\section{0. Čachtice}

a. Trenčín district.

b. Unknown.

c. 4-6 axe-shaped bars, 2 ploughshares.

d. Bialeková 1990, 110

\section{1. Čebovce}

a. Banská Bystrica district.

b. Nearby settlement.

c. 4 sickles, 2 ploughshares, 1 scythe, 1 coulter, 1 axe-shaped bar, 1 hoe.

d. Točí́ 1983, 207.

\section{Divinka I.}

a. Žilina district.

b. Hillfort.

c. 1 scythe, 4 sickles, 1 drawknife, 1 chopper, 1 chisel, 1 tail skid, 1 smithing.

d. TurČAn 2012, 25-26.

\section{Divinka II.}

a. Žilina district.

b. Hillfort

c. Silesian basin, ploughshare, coulter, sickle, scythe, hoe, axe, key.

d. FUSEK 2017, 34

\section{Divinka III}

a. Žilina district.

b. Hillfort.

c. Silesian bowls, horseshoe, bucket parts.

d. FUSEK 2017, 34-35.

\section{Dolná Mariková}

a. Trenčín district.

b. Hillfort.

c. ploughshares, scythes, coulters, axe-shaped bars, spurs, arrow heads, a bucket mounting.

d. Borzová 2016, 130.

\section{Gajary I.}

a. Bratislava district.

b. Settlement.

c. 2 sickles, Bronze mountings.

d. ČILINSKÁ 1984, 163. - ZÁвOJNíK 2009, 91.

\section{Gajary II}

a. Bratislava district.

b. Settlement.

c. 8 fragments of sickles, 4 scythes, 2 coulters, 2 scissors, 1 mattock, $1 \mathrm{~L}$-shaped key, 1 Silesian basin, 9 parts of bucket, 3 stirrups, 1 lance head, 2 files.

d. ČIlinskÁ 1984, 163. - BARTošKová 1986, 11. - ZÁвojNík 2009, 92.

\section{Gajary III.}

a. Bratislava district.

b. Unknown.

c. 1 mattock, 1 coulter, 2 scythe, 1 ploughshare, 1 scissors, 1 Silesian basin, 1 knife, 1 bucket holder, 1 sword.

d. ČILINSKÁ 1984, 164. - BARTOŠKOvá 1986, 17-18.

\section{Hrádok}

a. Trenčín district.

b. Hillfort.

c. 247 axe-shaped bars.

d. BARtošKová 1986, 18. - Bialeková 1990, 110.

\section{Horné Plachtince}

a. Banská Bystrica district.

b. Unknown.

c. 3 axes, 1 lance head, 1 chopper, 1 sickle, 1 iron waist, 1 mounting, 1 bucket mounting, 1 arrow head, 73 iron fragments.

d. TURČAn 2012, 27-29.

\section{Komjatice}

a. Nitra district.

b. Settlement.

c. 1 sickle, 1 scissors.

d. ŠALKOVSKÝ, VLKOLINSKÁ 1987, 127-171.

\section{Kúty I.}

a. Trnava district.

b. Settlement.

c. 4 sickles, 1 stirrup, 1 Silesian basin?

d. BARTošKová 1986, 22. - ZÁ́ojník 2009, 101.

33. Kúty II.

a. Trnava district.

b. Settlement.

c. 1 ploughshare, 1 scythe, 1 sickle, 1 spud, 2 L-shaped keys, 1 stirrup.

d. BARTošKová 1986, 22. - ZÁвOJNíK 2009, 101-102.

\section{Kúty III.}

a. Trnava district.

b. Unknown.

c. 1 ploughshare, 1 axe, 1 spud, 1 half of scissors.

d. BARTOŠKOVÁ 1986, 22-23.

\section{Modra}

a. Bratislava district.

b. Hillfort.

c. 1 coulter, 1 ploughshare.

d. FARKAš 2001, 155. 


\section{Moravský Ján}

a. Trnava district.

b. By the river Morava.

c. In cauldron, covered by another? 1 ploughshare, 1 mattock,

2 hoes, 1 coulter, 3 knifes, 1 lance head, 2 axes, 1 key, 1 share,

2 hammers, 1 wimble, 2 iron circles, 1 hook, 3 snaffles, 2 stirrups,

1 chain, Bronze artefacts.

d. BARTošKová 1986, 33. - ZÁ́̈OJNík 2009, 103.

\section{Nitra-Šindolka}

a. Nitra district.

b. Settlement.

c. 23 axe-shaped bars.

d. Bialeková 1990, 111.

\section{Oborín}

a. Košice district.

b. Settlement.

c. 1 sickle, pottery.

d. VizDAL 1963, 372-377.

\section{Palánok}

a. Nitra district.

b. Unknown.

c. 2 ploughshares, 7 sickles, 2 hoes.

d. Henning 1987, 139. - CurTa 1997, 258.

\section{Pobedim I.}

a. Trenčín district.

b. Hillfort.

c. I: 49 axe-shaped bars.

d. Bialeková 2008, 337.

\section{Pobedim II.}

a. Trenčín district.

b. Hillfort.

c. II: 22 axe-shaped bars, 1 sickle, 1 coulter, half of 1 snaffle, 5 spurs.

d. BartošKová 1986, 38-40. - Bialeková 1990, 111. - Bialeková 2008, 337.

\section{Pobedim III.}

a. Trenčín district.

b. Hillfort.

c. V: 111 axe-shaped bars, spurs, snaffles, mountings.

d. Bialeková 1990, 111. - Bialeková 2008, 337.

\section{Pobedim IV.}

a. Trenčín district.

b. Hillfort.

c. VII: 142 axe-shaped bars, iron tools.

d. Bialeková 1990, 111. - Bialeková 2008, 337.

\section{Pobedim V.}

a. Trenčín district.

b. Hillfort.

c. IX: 42 axe-shaped bars.

d. Bialeková 1990, 111. - Bialeková 2008, 337.

\section{Pobedim VI.}

a. Trenčín district.

b. Hillfort.

c. X: 7 axe-shaped bars, iron tools.

d. Bialeková 1990, 111. - Bialeková 2008, 337.

\section{Pobedim VII.}

a. Trenčín district.

b. Hillfort.

c. XI: 50 axe-shaped bars, iron tools.

d. Bialeková 1990, 111.

\section{Pobedim VIII.}

a. Trenčín district.

b. Hillfort.

c. XVII: 9 axe-shaped bars, iron tools.

d. Bialeková 1990, 112. - Bialeková 2008, 337.

\section{Pobedim IX.}

a. Trenčín district.

b. Hillfort.

c. XIX: 71 axe-shaped bars.

d. Bialeková 1990, 112. - Bialeková 2008, 337.

\section{Pobedim X.}

a. Trenčín district.

b. Hillfort.

c. XX: 30 axe-shaped bars.

d. Bialeková 1990, 112. - Bialeková 2008, 337.

\section{Pobedim XI.}

a. Trenčín district.

b. Hillfort.

c. XXII: 6 axe-shaped bars.

d. Bialeková 1990, 112. - Bialeková 2008, 337.

\section{Pobedim XII.}

a. Trenčín district.

b. Hillfort.

c. III: 48 axe-shaped bars.

d. Bialeková 1990, 112. - Bialeková 2008, 337.

\section{Pobedim XIII.}

a. Trenčín district.

b. Hillfort.

c. IV: 222 axe-shaped bars, 117 iron fragments.

d. Bialeková 1990, 112. - Bialekové 2008, 337.

\section{Pobedim XIV.}

a. Trenčín district.

b. Hillfort.

c. VIII: 65 axe-shaped bars.

d. Bialeková 1990, 112. - Bialeková 2008, 337.

\section{Pobedim XV.}

a. Trenčín district.

b. Hillfort.

c. XII: 56 axe-shaped bars.

d. Bialeková 1990, 112. - Bialeková 2008, 337. 


\section{Pobedim XVI.}

a. Trenčín district.

b. Hillfort.

c. XV: 9 axe-shaped bars.

d. Bialeková 1990, 112. - Bialeková 2008, 337.

\section{Pobedim XVII.}

a. Trenčín district.

b. Hillfort.

c. XVI: 124 axe-shaped bars, iron tools.

d. Bialeková 1990, 112. - Bialeková 2008, 337.

\section{Pobedim XVIII.}

a. Trenčín district.

b. Hillfort.

c. VI: 69 axe-shaped bars.

d. Bialeková 1990, 112.

\section{Pobedim XIX.}

a. Trenčín district.

b. Settlement.

c. XIII: 17 axe-shaped bars, iron tools.

d. Bialeková 2008, 337.

\section{Pobedim XX.}

a. Trenčín district.

b. Settlement.

c. XIV: 30 axe-shaped bars.

d. Bialekové 1990, 112.

\section{Pobedim XXI.}

a. Trenčín district.

b. Settlement.

c. XVIII: 28 axe-shaped bars, iron tools.

d. Bialeková 1990, 112.

\section{Prosiek}

a. Žilina district.

b. Hillfort.

c. 1 bucket holder, 1 bucket mounting, 1 stirrup, 2 spurs, 1 lance head, 1 coulter.

d. Pieta 2016, 261-265.

\section{Pružina}

a. Trenčín district.

b. Hillfort.

c. 4 ploughshares, 5 coulters, 4 scythes, 1 hoe, 2 axes, 3 saw, 1 spike, 1 drawshare, 8 spurs, 4 stirrups, 1 knife, 3 snaffles, 4 keys, axeshaped bars, 4 Silesian basins, c. 10 small tools.

d. Borzová 2005, 167. - Pieta 2012, 94-97.

\section{Radvaň nad Dunajom}

a. Nitra district.

b. Unknown.

c. 2 coulters, plates decorated by little pearls, 6 axes.

d. ČILINSKÁ 1984, 164. - Zа́вOJNíк 2009, 111.

\section{Sklabiňa}

a. Banská Bystrica district.

b. Unknown.

c. 1 ploughshare, 1 coulter, 1 hoe, 1 chisel-formed stylus, 2 spikes, 1 lance head, iron fragments.

d. BARTOšKová 1986, 53.

\section{Stráňavy}

a. Žilina district.

b. Unknown.

c. 4 sickles.

d. SLANÁ 2017, 44-45.

\section{Trenčianske Teplice}

a. Trenčín district.

b. Hillfort.

c. 3 sickles, 1 coulter.

d. NeŠPorová 2003, 97-109.

\section{Vel'ký Klíž}

a. Trenčín district.

b. By the forest spring.

c. 42 axe-shaped bars, 4 coulter, 1 sickle, 1 hammer, 1 axe, 1 bucket mounting, 12 parts of bucket circles.

d. TurčAn 2012, 30-32.

\section{Vyšný Kubín}

a. Žilina district.

b. Hillfort.

c. 3 bucket holders, 22 fragments from bucket, 2 sickles, 2 iron circles, iron strips, bucket mounting, iron fragments.

d. Pieta 2016, 271-274.

\section{Vrbové}

a. Trnava district.

b. Unknown.

c. 14 axe-shaped bars, 6 ploughshares, 6 sickles, 2 chisels, 1 bucket holder, 1 bucket band, 1 coulter, 1 wimble, 1 iron stick, 1 handle, 1 S-profiled mounting.

d. TurČAn 2012, 33-35.

\section{Vršatské Podhradie}

a. Trenčín district.

b. Unknown.

c. 1 scythe, 1 ploughshare, 1 coulter, 3 hoes, 1 wimble, 2 axes, 1 spike, 2 drawshare, 4 tongs, 3 anvils, 1 axe-shaped bar.

d. BARTošKová 1986, 59-60.

\section{Zádiel}

a. Košice district.

b. By the stream.

c. 1 ploughshare, 2 coulters.

d. BARTošKová 1986, 60.

\section{Zemianske Podhradie}

a. Trenčín district.

b. Unknown. 
c. 11 axe-shaped bars, 4 belts, 1 scissors, 1 stick, 4 mountings, 2 drawshares, 1 key, 1 bell-formed tool, 1 spur, 1 sickle knife, 2 choppers, 3 knifes, 2 circle mounting, 1 saw, 2 coulters, 3 scythes, 3 ploughshares, 1 stirrup, 1 axe.

d. TuRČAn 2012, 36-38.

\section{3. Žabokreky nad Nitrou I.}

\section{a. Trenčín district.}

b. Settlement.

c. 3 sickles, 2 scythes, 1 ploughshare, 1 coulter, 1 cauldron, 6 axeshaped bars.

d. НАвоvštiak 1965, 58. - BARTošKová 1986, 60-61.

\section{4. Žabokreky nad Nitrou II.}

a. Trečín district.

b. Settlement.

c. 8 sickles, 4 scythes, 4 ploughshares, 2 coulters, 1 hoe, 2 spuds, 1 axe, 1 drawshare, 2 chisels, 1 wimble, 1 L-shaped key, fragment of bucket holder, bucket bands, 10 axe-shaped bars.

d. Točí́ 1963, 601. - Навovštiak 1965, 58. - BartošKová 1986, 62-63.

\section{References}

BARTOŠKovÁ 1986

A. BARTošKovÁ, Slovanské depoty ñelezných předmětů v Československu / Slawische Hortfunde von Eisengegenständen in der Tschechoslowakei. Studie Archeologického ústavu ČSAV v Brně 13/2, Prague 1986.

BERANOVÁ 1988

M. Beranová, Slované. Prague 1988.

BiALEKová 1990

D. Bialeková, Sekerovité hrivny a ich väzba na ekonomické a sociálne prostredie Slovanov. In: L. GALUŠKa (Ed.), Staroměstská výročí. Brno 1990, 99-119.

BiALEKová 2008

D. Bialeková, Depotfunde von Axtbarren und Eisengegenständen - ein Phänomen des Pobedim- Burgwalls und seines ökonomischen Hinterlandes. In: L. POLÁčEK (Ed.), Das wirtschaftliche Hinterland der frühmittelalterlichen Zentren. Internationale $\mathrm{Ta}-$ gungen in Mikulčice VI, Brno 2008, 337-344.

Bialeková 2017

D. Bialeková, Ein Gürtelbeschlag vom Burgwall in Pobedim. In: G. Fusek (Ed.), Archäologische Studien zum frühen Mittelalter. Nitra 2017, 11-13.

Bialeková, KamHalová 2000

D. Bialeková, M. Kamhalová, Slovanské sekerovité hrivny z depozitu Múzea Mincí a Medailí v Kremnici, Archeologické výskumy a nálezy na Slovensku v roku 1998, 2000, 34-36.

BINFORD 1962

L. Binford, Archaeology as anthropology, American Antiquity 28/2, 1962, 217-222.

Borzové 2005

Z. Borzová, Polnohospodárske náradia a nástroje v období 6.12. storočia na území dnešného Slovenska. PhD Dissertation, University Nitra 2005.

Borzová 2006

Z. Borzové, Kosáky v hroboch z obdobia včasného stredoveku na Slovensku / Sickles in medieval graves in Slovakia, Slovenská Archeológia LIV/2, 2006, 209-237.
Borzová 2016

Z. Borzové, Polnohospodárske náradie včasného stredoveku na Slovensku. Nitra 2016.

BRADLEY 1990

R. BRAdley, The Passage of Arms: An Archaeological Analysis of Prehistoric Hoards and Votive Deposits. Oxford - Oakville 1990.

ČILINSKÁ 1984

Z. ČILINSKÁ, Depoty ñelezných predmetov z konca 8. stor. na Slovensku. In: E. STudeníková (Ed.), Zborník prác Ludmile Kraskovskej. Bratislava 1984, 163-171.

CurTa 1997

F. CURTA, Blacksmiths, warriors, and tournaments of value: dating and interpreting early medieval hoards of iron implements in eastern Europe, Ephemeris Napocensis 7, 1997, 211-268.

EGGERT 2001

M. K. H. Eggert, Prähistorische Archäologie: Konzepte und Methoden. Tübingen - Basel 2001.

FARKAŠ 2001

Z. FARKAš, Zistovací výskum v Modre, poloha Zámčisko, Zborník Slovenského Národného Múzea 95 Archeológia 11, 2001, 135168.

FUSEK 2017

G. Fusek, Kleiner Hortfund von Divinka. In: G. Fusek (Ed.), Archäologische Studien zum frühen Mittelalter. Nitra 2017, 33-43.

GORECKI 1995

J. GoRecki, Die Münzbeigabe, eine mediterrane Grabsitte: Nur Fährlohn für Charon? In: M. WitTeyer (Ed.), Des Lichtes beraubt: Totenehrung in der römischen Gräberstraße von MainzWeisenau (Exhibition catalogue, Frankfurt 1995, Kassel 1996). Mainz 1995, 93-103.

НАвоvŠTIAK 1965

A. HaвovšTiaK, Polnohospodárstvo na Slovensku v 9.-11. storočí. In: O počiatkoch slovenských dejín: sborník materiálov. Materiály z konferencie o počiatkoch feudalizmu na Slovensku konanej 12. -14 . novembra 1963 v Smoleniciach. Bratislava 1965, 55-80.

HAHN 2015

H. P. HAHN, Geliebt, geschätzt, verachtet: Zur Dynamik der Be- und Umwertung materieller Dinge, Beiträge zur Mittelalterarchäologie in Österreich 31, 2015, 9-16.

HANULIAK 2004

M. Hanuliak, Velkomoravské pohrebiská. Pochovávanie v 9. -10. storočí na území Slovenska. Nitra 2004.

HenNing 1987

J. Henning, Südosteuropa zwischen Antike und Mittelalter: Archäologische Beiträge zur Landwirtschaft des 1. Jahrtausends u. Z. Schriften zur Ur- und Frühgeschichte 42, Berlin 1987.

HeNNING et al. 2015

J. Henning, K. U. Heussner, K. Pieta, M. Ruttkay, Bojná a datovanie hradísk Nitrianskeho kniežatstva: Prínos prírodovedných metód $\mathrm{k}$ archeologickému výskumu. In: K. Pieta, Z. RoвaK (Eds.), Bojná 2: Nové výsledky výskumov včasnostredovekých hradísk. Nitra 2015, 335-344.

HODDER 2017

I. Hodder, Entangled: An Archaeology of the Relationships between Humans and Things. West Sussex 2017.

JOLLIFFE 2002

I. T. Jolliffe, Principal Component Analysis. New York 2002. 


\section{KILGER 2011}

C. C. L. Kilger, Hack-silver, weights and coinage: the Anglo-Scandinavian bullion coinages and their use in late Viking-Age society. In: J. Graham-Campbell, S. Sindbek, G. Williams (Eds.), Silver Economies, Monetisation and Society in Scandinavia, AD 800-1100. Aarhus 2011, 257-278.

KIPFER 2000

B. A. Kipfer, Encyclopedic Dictionary of Archaeology. New York 2000.

KOUŘIL 2016

P. KouŘil, Starí Mad’aři a jejich podíl na kolapsu Velké Moravy aneb spojenci, sousedé, nepřátelé. In: J. MACHÁčEK, M. WIHODA (Eds.), Pád Velké Moravy aneb Kdo byl pohřben v hrobu 153 na Pohansku u Břeclavi. Brno 2016, 102-143.

KovÁč 2013

J. Kováč, Hromadný nález železných predmetov z Bratislavského hradného vrchu, Zborník Slovenského Národného Múzea 107 Archeológia 23, 2013, 97-103.

KüNZL 1996

E. KüNZL, Anmerkungen zum Hortfund von Weißenburg, Germania 74, 1996, 453-476.

МАСНÁČEK 2013

J. МАснÁčEK, Greatmoravian central places and their practical function, social significance and symbolic meaning. In: P. ETTEL, L. Werther (Eds.), Zentrale Orte und zentrale Räume des Frühmittelalters in Süddeutschland. Tagung des Römisch-Germanischen Zentralmuseums Mainz und der Friedrich-SchillerUniversität Jena vom 7.-9.10.2011 in Bad Neustadt an der Saale. Mainz 2013, 235-248.

МACHÁČEK 2015

J. МАснÁčEK, O Velké Moravě, archeologií raného středověku i o nás samých, Archeologické rozhledy LXVII, 2015, 464-494.

Mazuch, Hladík, Skopal 2017

M. Mazuch, M. Hladík, R. Skopal, Úpravy hrobových jám a dřevené konstrukce v hrobech na pohřebištích Velké Moravy (Sociální, duchovní a chronologický fenomén). Brno 2017.

Montelius 1903

O. Montelius, Die älteren Kulturperioden im Orient und in Europa. Stockholm 1903.

Múcska, Daniš, ŠEvčíková 2006

V. MúcSKa, M. Daniš, Z. Š EvČí́коvÁ, Dejiny európskeho stredoveku I: Raný stredovek (od 5. do polovice 11. storočia). Prešov 2006.

NeŠPorová 2003

T. NEŠPOROvÁ, Príspevok k včasnostredovekému až neskorostredovekému osídleniu stredného Považia, Musaica 24, 2003, 97-109.

NeustupnÝ 1997

E. NeustupNÝ, Syntéza struktur formalizovanými metódami - vektorová syntéza. In: J. MACHÁČEK (Ed.), Počítačová podpora v archeológii I. Brno 1997, 237-258.

NeUSTUPNÝ 2007

E. NeustupnÝ, Metoda Archeologie. Pilsen 2007.

NeustupnÝ 2010

E. NeustupnÝ, Teorie Archeologie. Pilsen 2010.

NovotnÝ 1986

B. Novotný, Encyklopédia Archeológie. Bratislava 1986.

PiETA 2007

K. PiETA, Bojná, Nové nálezy k počiatkom slovenských dejín. Bojná 2007.
Pieta 2012

K. Pieta, Mesciská: Pružina. In: V. Turčan (Ed.), Velkomoravské hradiská. Bratislava 2012, 94-97.

Pieta 2016

K. Pieta, Hromadné nálezy z Prosieka a Vyšného Kubína: Poznámky k včasnostredovekému osídleniu Liptova a Oravy, Slovenská Archeológia LXIV/2, 2016, 261-279.

Pieta, RutTKay 2007

K. Pieta, A. RutTkay, Bojná - Mocenské a christianizačné centrum Nitrianskeho kniežatstva. In: K. Pieta, M. Ruttkay, A. RutTKAY (Eds.), Bojná: Hospodárske a politické centrum Nitrianskeho kniežatstva. Nitra 2007.

RENFREW 1972

C. Renfrew, The Emergence of Civilisation: The Cyclades and the Aegean in the Third Millennium B.C. London 1972.

RENFREW 2009

C. Renfrew, Prehistória: Formovanie ludskej mysle [Slovak translation of C. Renfrew's Prehistory: The making of the human mind from 2007]. Bratislava 2009.

ŠALKOVSKÝ 2002

P. ŠALKOvSKÝ, Sekerovité hrivny a d’alšie včasnostredoveké nálezy z hradiska v Bojnej, Študijné Zvesti Archeologického ústavu SAV 34, 2002, 171-178.

ŠALKOVSKÝ, VLKOLINSKÁ 1987

P. ŠALKOVSKÝ, I. VLKOLINSKÁ, Včasnostredoveké a vrcholnostredoveké sídlisko v Komjaticiach, Študijné Zvesti Archeologického ústavu SAV 23, 1987, 127-172.

SLANÁ 2017

A. SLANÁ, Stredoveké žacie a zberové náradie v zbierkach Považského múzea v Žiline / Medieval reaping and harvesting tools in the collections of Považské Museum in Žilina, Vlastivedný zborník Považia 28, 2017, 39-68.

SмITH 2004

M. E. Sмiтн, The archaeology of ancient state economies, Annual Review of Anthropology 33, 2004, 73-102.

ŠTEFAN 2011

I. Štefan, Great Moravia, statehood and archaeology. In: J. MacháčEK, Š. Ungerman (Eds.), Frühgeschichtliche Zentralorte in Mitteleuropa. Bonn 2011, 333-354.

ŠTEFAN 2014

I. ŠTEFAn, Mocní náčelníci od řeky Moravy? Poznámky ke struktuře raných státu, Archeologické rozhledy LXVI, 2014, 141-176.

ŠTEFANOVIČOVÁ 2008

T. ŠTEFANOvičová, Slovensko v 10. storočí. In: T. ŠTteFANOvičová, D. Hulínek (Eds.), Bitka pri Bratislave v roku 907 a jej význam pre vývoj stredného Podunajska. Bratislava 2008, 137-148.

STEINHÜBel 2004

J. STEINHÜвEL, Nitrianske kniežatstvo. Bratislava 2004.

TAINTER 2009

J. A. Tainter, Kolapsy složitých společností [Czech translation of J. A. Tainter's The collapses of complex societies from 1988]. Prague 2009.

Točík 1983

A. Točík, Velkomoravský železý depot z Čeboviec, Študijné Zvesti Archeologického ústavu SAV 20, 1983, 207-228.

TURČAN 2012

V. TuRČAN, Depoty z Bojnej a včasnostredoveké hromadné nálezy železných predmetov uložené v zbierkach SNM-Archeologického múzea. Bratislava 2012. 
URBANCZYK 2009

P. Urbanczyk, The Polish discussion on medieval deposits of hack-silver, Historia Archaeologica 70, 2009, 499-521.

VanPool, Leonard 2011

T. L. VanPool, R. D. Leonard, Quantitative Analysis in Archaeology. Chichester 2011.

VIZDAL 1963

J. VizDAL, Hromadný nález slovanských nádob v Oboríne, Archeologické rozhledy XV, 1963, 365-366, 372-376.

WeBER 1997

Z. Weber, Statistická analýza archeologických dat. In: J. MACHÁčEK (Ed.), Počítačová podpora v archeológii I. Brno 1997, 197-214.

ZÁвоJNík 2009

J. ZÁвојNíк, Slovensko a Avarský kaganát. Bratislava 2009.

Mária Múllerová Department of Archaeology and Museology Faculty of Arts Masaryk University Brno Arna Novaka 1 60200 Brno Czech Republic marika.mullerova@gmail.com D orcid.org/0000-0003-0768-0363 